\title{
Pengaruh Penerapan Model Pembelajaran Probing Prompting dan Contextual Teaching and Learning Terhadap Hasil Belajar Ditinjau dari Motivasi Belajar Siswa Sekolah Menengah Kejuruan
}

\author{
Putri Yulia ${ }^{1}$ Sri Utami Ningsih ${ }^{2}$ \\ ${ }^{I}$ Fakultas Tarbiyah dan Ilmu Keguruan IAIN Kerinci \\ ${ }^{2}$ Universitas Riau Kepulauan Batam \\ putriyuliamz@gmail.com
}

\begin{abstract}
The purpose of this research is to determine: (1) Differences of students learning result using Probing-Prompting models and Contextual Teaching and Learning (2) Differences in learning outcomes between students who have low motivation, moderate and high. (3) Interaction between learning model (Probing-Prompting and Contextual Teaching and Learning) with student's learning motivation.This type of research is a experiment research with factorial design $2 \times 3$. The population of this research is all students in ten class of SMK Teladan Batam. Sampling was done by cluster random sampling technique, therefore the research sample is two clasess, class X Teknik Kendaraan Ringan as an experimental class I and class X Teknik Konstruksi Kapal Baja as an experimental class II. The instrument of data colletion applied was the value of midterm test II, questionnaire about learning motivation, and the result of learning mathematic lessons test. The prerequisite test included the population normality test using Lilliefors method and homogeneity test of population variance using Bartlett method. The hypothesis testing was done using a two-way analysis of variance with different cell. The result of research showed thaht: (1) The Probing-Prompting models and Contextual Teaching and Learning the same learning outcomes. (2) The result of student learning which has a low learning motivation, medium, and high education outcomes are the same. (3) There is no interaction between the learning (Probing Prompting and Contextual Teaching and Learning) with the learning motivation.
\end{abstract}

Keywords: Probing Prompting, Contextual Teaching and Learning, Motivation and Learning Outcome

\begin{abstract}
Abstrak. Penelitian ini bertujuan untuk mengetahui: (1) Perbedaan hasil belajar antara siswa yang diberi perlakuan model pembelajaran Probing-Prompting dan Contextual Teaching and Learning. (2) Perbedaan hasil belajar antara siswa yang memiliki motivasi rendah, sedang dan tinggi. (3) Interaksi antara model pembelajaran (Probing-Prompting dan Contextual Teaching and Learning) dengan motivasi belajar siswa. Jenis penelitian ini adalah penelitian eksperimen dengan desain faktorial $2 \times 3$. Populasi penelitian ini adalah seluruh siswa SMK Teladan Kota Batam Kelas X. Pengambilan sampel dilakukan dengan teknik Cluster Random Sampling. Sampel dalam penelitian ini sebanyak dua kelas yaitu kelas X Teknik Kendaraan Ringan sebagai kelas ekperimen I dan kelas X Teknik Konstruksi Kapal Baja sebagai kelas eksperimen II. Instrumen yang digunakan untuk mengumpulkan data adalah nilai ujian tengah semester II, angket motivasi belajar, dan tes hasil belajar matematika. Uji prasyarat meliputi uji normalitas menggunakan metode Lilliefors dan uji homogenitas menggunakan metode Bartlett. Pengujian hipotesis menggunakan analisis variansi dua jalan dengan sel tak sama. Hasil penelitian menunjukkan: (1) Model pembelajaran Probing-Prompting dan Contextual Teaching and Learning menghasilkan hasil belajar yang sama. (2) Hasil belajar siswa yang memiliki motivasi belajar rendah, sedang dan tinggi memiliki hasil belajar yang sama. (3) Tidak terdapat interaksi antara model pembelajaran (Probing-Prompting dan Contextual Teaching and Learning) dengan motivasi belajar.
\end{abstract}

Kata kunci: Probing Prompting, Contextual Teaching and Learning, Motivasi dan Hasil Belajar 


\section{PENDAHULUAN}

Pada umumnya pembelajaran matematika di sekolah menuntut guru untuk dapat melatih cara berpikir dan bernalar siswa. Seorang guru diharapkan memiliki keterampilan baik dalam menggunakan maupun mengembangkan model pembelajaran yang efektif, kreatif dan menyenangkan. Berdasarkan hasil observasi yang peneliti lakukan pada bulan Januari-Februari 2016 di SMK Teladan Kota Batam pada siswa kelas X, terlihat pada umumnya guru hanya memberikan materi pembelajaran, dilanjutkan dengan siswa mengerjakan lembar tugas secara individu . Selain hal tersebut, berdasarkan hasil wawancara terhadap guru bidang studi matematika terungkap bahwa dalam kegiatan belajar mengajar untuk model pembelajaran belum dilakukan inovasi baru untuk membantu siswa memahami materi yang disampaikan, dimana pembelajaran masih berpusat pada guru.

Disamping wawancara terhadap guru, peneliti juga melakukan wanwancara terhadap beberapa siswa, dapat disimpulkan bahwasanya siswa menganggap matematika adalah pelajaran yang rumit dan sulit dimengerti, sehingga mereka kurang termotivasi untuk mengikuti pelajaran. Permasalahan lain yang terlihat adalah hasil belajar siswa yang masih rendah, hal ini terlihat dari persentase ketercapaian KKM nilai ujian semester ganjil siswa kelas X SMK Teladan Kota Batam yang masih dibawah persentase yang diharapkan. Salah satu model pembelajaran yang dirasa mampu untuk mengatasi permasalahan tersebut yaitu model pembelajaran Probing-Prompting (PP) dan Contextual Teaching and Learning (CTL).

Menurut arti katanya, probing adalah penyelidikan, pemeriksaan, sementara prompting adalah mendorong atau menuntun. Menurut Suherman (dalam Huda, 2013:281) pembelajaran probing-prompting adalah pembelajaran dengan menyajikan serangkaian pertanyaan yang sifatnya menuntun dan menggali gagasan siswa sehingga dapat melejitkan proses berpikir yang mampu mengaitkan pengetahuan dan pengalaman siswa dengan pengetahuan baru yang sedang dipelajari.

Dapat disimpulkan bahwa pembelajaran probing-prompting merupakan konsep pembelajaran yang bersifat terbuka dan terarah pada satu tujuan yaitu menggali pengetahuan siswa. Model pembelajaran probing-prompting ini juga dapat mengidentifikasi kemampuan, nalar, daya tangkap, dan keaktifan peserta belajar. Sudarti (dalam Huda, 2013:282) menjabarkan langkahlangkah pembelajaran probing-prompting sebagai berikut:

a. Guru menghadap siswa pada situasi baru, misalkan dengan membeberkan gambar, rumus, atau situasi lainnya yang mengandung permasalahan.

b. Menunggu beberapa saat untuk memberikan kesempatan kepada siswa untuk merumuskan jawaban atau melakukan diskusi kecil dalam merumuskan permasalahan.

c. Guru mengajukan persoalan yang sesuai dengan tujuan pembelajaran khusus (TPK) atau indikator kepada seluruh siswa.

d. Menunggu beberapa saat untuk memberikan kesempatan kepada siswa untuk merumuskan jawaban atau melakukan diskusi kecil.

e. Menunjuk salah satu siswa untuk menjawab pertanyaan.

f. Jika jawabannya tepat, maka guru meminta tanggapan kepada siswa lain tentang jawaban tersebut untuk meyakinkan bahwa seluruh siswa terlibat dalam kegiatan yang sedang berlangsung. Namun, jika siswa tersebut mengalami kemacetan jawaban atau jawaban yang diberikan kurung tepat, tidak tepat, atau diam, maka guru mengajukan pertanyaanpertanyaan lain yang jawabannya merupakan petunjuk jalan penyelesaian jawaban. Kemudian, guru memberikan pertanyaan yang menuntut siswa berpikir pada tingkat yang lebih tinggi, sehingga siswa dapat menjawab pertanyaan sesuai dengan kompetensi dasar atau indikator. Pertanyaan yang diajukan pada langkah keenam ini sebaiknya diberikan pada beberapa siswa yang berbeda agar semua siswa terlibat dalam seluruh kegiatan probingprompting.

g. Guru mengajukan pertanyaan akhir pada siswa yang berbeda untuk lebih menekankan bahwa indikator tersebut benar-benar telah dipahami oleh seluruh siswa.

Pemilihan model pembelajaran Probing-Prompting dapat memacu siswa untuk aktif karena pada model pembelajaran ini guru akan memberikan pertanyaan kepada siswa yang ditunjuk secara 
acak sehingga setiap siswa mau tidak mau harus berpartisipasi aktif. Contextual Teaching and Learning atau sering disebut dengan CTL pemilihan model pembelajaran ini menjadikan siswa mampu mengaitkan materi pembelajaran dengan penerapannya dalam kehidupan sehari-hari. Pembelajaran kontekstual atau Contextual Teaching and Learning (CTL) adalah konsep belajar yang membantu guru mengaitkan antara materi pembelajaran dengan situasi dunia nyata siswa, dan mendorong siswa membuat hubungan antara pengetahuan yang dimilikinya dengan penerapannya dalam kehidupan mereka sehari-hari (US Department of Education Office of Vocational and Adult Education and the National School to Work Office)(dalam Masnur, 2009:41).

Menurut Elaine B. Johnson (dalam Rusman, 2013:187) mengatakan pembelajaran kontesktual adalah sebuah sistem yang merangsang otak untuk menyusun pola-pola yang mewujudkan makna.Lebih lanjut, Elaine mengatakan bahwa pembelajaran kontekstual adalah suatu sistem pembelajaran yang cocok dengan otak yang menghasilkan makna dengan menghubungkan muatan akademis dengan konteks dari kehidupan sehari-hari.

Dari beberapa pendapat diatas, maka dapat ditarik suatu kesimpulan teori, bahwa konsep pembelajaran kontekstual merupakan konsep belajar yang mampu meransang ketangkasan, kecakapan, dan reaksi berpikir siswa dalam pengaitan antara materi pelajaran dengan kehidupan sehari-hari.

Adapun langkah-langkah pembelajaran (CTL) sebagai berikut, Aris (2016:43):

a. Siswa bekerja dalam kelompok menyelesaikan permasalahan yang diajukan guru. Guru berkeliling untuk memandu proses penyelesaian permasalahan (Learning Community, Inquiry, Questioning).

b. Siswa wakil kelompok mempresentasikan hasil penyelesaian dan alasan atas jawaban permasalahan yang diajukan guru (Constructivism).

c. Siswa dalam kelompok menyelesaikan lembar kerja yang diajukan guru. Guru berkeliling untuk mengamati, memotivasi, dan memfasilitasi kerjasama (Learning Community, Inquiry, Questioning).

d. Siswa wakil kelompok mempresentasikan hasil kerja kelompok dan kelompok yang lain menanggapi hasil kerja kelompok yang mendapat tugas (Modelling).

e. Dengan mengacu pada jawaban siswa, melalui tanya jawab, guru dan siswa membahas cara penyelesaian masalah yang tepat (Questioning).

f. Guru mengadakan refleksi dengan menanyakan kepada siswa tentang hal-hal yang dirasakan siswa, materi yang belum dipahami dengan baik, kesan dan pesan selama mengikuti pembelajaran (Reflection).

g. Guru dan siswa membuat kesimpulan (Reflection).

h. Siswa mengerjakan lembar tugas (Authentic Assessment).

Menurut Mc.Donald (dalam Sardiman, 2009:73) motivasi adalah perubahan energi dari dalam diri seseorang yang ditandai dengan munculnya "feeling" dan didahului dengan tanggapan terhadap adanya tujuan. Motivasi merupakan kondisi psikologis yang mendorong seseorang untuk melakukan sesuatu, Pupuh \& Sobry (2009:19). Sardiman (2009:75) juga mengemukakan pendapatnya bahwa motivasi dapat juga dikatakan serangkaian usaha untuk menyediakan kondisikondisi tertentu, sehingga seseorang mau dan ingin melakukan sesuatu, dan bila ia tidak suka, maka akan berusaha untuk meniadakan atau mengelakkan persaan tidak suka itu.

Berdasarkan beberapa pengertian tersebut dapat disimpulkan bahwa motivasi adalah pendorong dari dalam diri seseorang untuk melakukan sesuatu yang didasari oleh keinginan pencapaian tujuan tertentu.Indikator motivasi belajar dapat diklasifikasikan sebagai berikut Hamzah (2011:23): (a) Adanya hasrat dan keinginan berhasil; (b) Adanya dorongan dan kebutuhan dalam belajar; (c) Adanya harapan dan cita-cita masa depan; (d) Adanya penghargaan dalam belajar; (e) Adanya kegiatan yang menarik dalam belajar; dan (f) Adanya lingkungan belajar yang kondusif, sehingga memungkinkan seorang siswa dalajar dengan baik.

Dari paparan di atas maka melalui penelitian ini, penulis mencoba untuk menggali lebih jauh tentang pengaruh penerapan model pembelajaran probing prompting dan contextual teaching and learning terhadap hasil belajar ditinjau dari motivasi belajar siswa Sekolah Menengah Kejuruan 
(SMK). Tujuan penelitian ini adalah untuk mengetahui: (1) Perbedaan hasil belajar antara siswa yang diberi perlakuan model pembelajaran Probing-Prompting dan Contextual Teaching and Learning. (2) Perbedaan hasil belajar antara siswa yang memiliki motivasi rendah, sedang dan tinggi. (3) Interaksi antara model pembelajaran (Probing-Prompting dan Contextual Teaching and Learning) dengan motivasi belajar siswa

\section{METODE}

Jenis penelitian yang digunakan adalah eksperimen dengan desain factorial (Factorial Design) dikarenakan penelitian dengan memperhatikan kemungkinan adanya variabelmoderator yang mempengaruhi perlakuan (variabel independen) terhadap hasil (variabel dependen). Desain penelitian ini menggunakan desain faktor 2 x 3 dengan sel tak sama. Adapun pada penelitian ini terdapat dua variabel bebas yaitu model pembelajaran (faktor A) dan motivasi belajar siswa (faktor B) serta interaksi antara model pembelajaran dengan motivasi belajar siswa (faktor AB) terhadap variabel terikatnya yaitu hasil belajar matematika.

Sampel dari penelitian adalah siswa 2 kelas di kelas X semester 2 SMK teladan Kota Batam. Dengan teknik cluster random sampling diperoleh kelas X Teknik Kendaraan Ringan (TKR) sebagai kelas eksperimen satu dan kelas X Teknik Konstruksi Kapal Baja (TKKB) sebagai kelas eksperimen dua. Adapun instrument yang digunakan dalam penelitian ini adalah Tes Hasil Belajar Siswa dan Angket Motivasi Belajar Siswa.

Teknik analisis data yang digunakan adalah uji normalitas dan uji homogenitas.Uji keseimbangan rata-rata yang digunakan adalah uji t Separated Varian. Uji Hipotesis penelitian ini menggunakan analisis variansi dua jalan $2 \times 3$ dengan sel tak sama. Jika $\mathrm{H}_{\mathrm{OA}}, \mathrm{H}_{\mathrm{OB}}$, dan $\mathrm{H}_{\mathrm{OAB}}$ ditolak, maka harus dilakukan uji lanjut pasca anava (uji komparasi ganda).

\begin{tabular}{ccccc}
\multicolumn{5}{c}{ Tabel 1. Desain Penelitian (Desain Faktor 2x3) } \\
\hline \multirow{2}{*}{$\begin{array}{c}3 \\
\text { Faktor A }\end{array}$} & Faktor B & \multicolumn{3}{c}{ Motivasi Belajar } \\
\cline { 3 - 5 } $\begin{array}{c}\text { Model Pembelajaran } \\
\text { (A) }\end{array}$ & PP $\left(\mathrm{A}_{1}\right)$ & $\mathrm{AB}_{11}$ & $\mathrm{AB}_{12}$ & $\mathrm{AB}_{13}$ \\
\cline { 2 - 5 } & $\mathrm{CTL}\left(\mathrm{A}_{2}\right)$ & $\mathrm{AB}_{21}$ & $\mathrm{AB}_{22}$ & $\mathrm{AB}_{23}$ \\
\hline
\end{tabular}

\section{HASIL DAN PEMBAHASAN}

Berdasarkan penelitian yang telah dilakukan, diperoleh data hasil belajar matematika siswa dan data motivasi siswa kelas eksperimen 1 dan 2. Untuk data motivasi akan dikategorikan menjadi tiga kategori yaitu motivasi tinggi, sedang dan rendah.

Tabel 2. Deskripsi Data Hasil Belajar Siswa

\begin{tabular}{ccccc}
\multicolumn{5}{c}{ Tabel 2. Deskripsi Data Hasil Belajar Siswa } \\
\hline No & Kelompok & Rata-rata & Standar Deviasi & N \\
\hline 1 & Eksperimen 1 & 70,57 & 15,24 & 33 \\
\hline 2 & Eksperimen 2 & 73,38 & 16,69 & 31 \\
\hline
\end{tabular}

Tabel 3. Deskripsi Data Motivasi Belajar Siswa

\begin{tabular}{ccccc}
\hline \multirow{2}{*}{ No } & \multirow{2}{*}{ Kelompok } & \multicolumn{3}{c}{ Motivasi Belajar } \\
\cline { 3 - 5 } & & Tinggi & Sedang & Rendah \\
\hline 1 & Eksperimen 1 & 70,57 & 15,24 & 33 \\
\hline 2 & Eksperimen 2 & 73,38 & 16,69 & 31 \\
\hline
\end{tabular}

Sebelum dilakukan analisis data, harus dilakukan uji normalitas dan uji homogenitas. Uji normalitas hasil belajar matematika siswa meliputi uji untuk kelompok siswa dengan 
model pembelajaran PP, model pembelajaran CTL, motivasi belajar tinggi, motivasi belajar sedang, dan motivasi belajar rendah. Uji normalitas dengan menggunakan metode Liliefors dengan hasil semua data pada kelompok siswa berdistribusi normal. Sedangkan uji Homogenitas yang digunakan dalam penelitian ini adalah uji Barlet untuk kelompok siswa dengan model pembelajaran PP dan CTL dan motivasi belajar dengan hasil data homogen. Setelah data diperoleh normal dan homogen maka dilanjutkan dengan uji anava dua jalan $2 \times 3$ dengan sel tak sama dengan taraf signifikansi 0,05 .

Tabel 2. Rangkuman Analisis Variansi Dua Jalan Dengan Sel Tak Sama

\begin{tabular}{ccccccc}
\hline Sumber & $\mathrm{JK}$ & $\mathrm{dk}$ & $\mathrm{RK}$ & $\mathrm{F}_{\mathrm{obs}}$ & $\mathrm{F}_{\alpha}$ & Keputusan Uji \\
\hline Baris (A) & 32,461 & 1 & 32,461 & 0,120 & 4,007 & $\mathrm{H}_{0}$ diterima \\
\hline Kolom (B) & 8,925 & 2 & 4,462 & 0,017 & 3,156 & $\mathrm{H}_{0}$ diterima \\
\hline Interaksi (AB) & 73,283 & 2 & 36,641 & 0,136 & 3,156 & $\mathrm{H}_{0}$ diterima \\
\hline Galat ( G ) & $15.677,156$ & 58 & 270,296 & - & - & - \\
\hline Total & $15.791,825$ & 63 & - & - & - & - \\
\hline
\end{tabular}

1. Hipotesis pertama, pada efek utama A (model pembelajaran), nilai statistik uji $\mathrm{Fa}=0,120$ dan Ftabel $=4,007$. Ternyata Fa < Ftabel. Hal ini berarti Fa $\notin$ DK. Dengan demikian H0A diterima. Hal ini berarti pada tingkat signifikansi $\alpha=0,05$ tidak terdapat perbedaan hasil belajar matematika antara siswa yang diberikan model pembelajaran Probing-Prompting dan model pembelajaran Contextual Teaching and Learning.

2. Hipotesis kedua, pada efek utama $B$ (motivasi belajar), nilai statistik uji $\mathrm{Fb}=0,017$ dan Ftabel $=3,156$. Ternyata $\mathrm{Fb}<$ Ftabel. Hal ini berarti $\mathrm{Fb}<$ Ftabel. Hal ini berarti $\mathrm{Fb} \notin \mathrm{DK}$. Dengan demikian H0B diterima. Hal ini berarti pada tingkat signifikansi $\alpha=0,05$ tidak terdapat perbedaan hasil belajar matematika antara siswa yang memiliki motivasi belajar yang rendah, sedang dan tinggi.

3. Hipotesis ketiga, pada efek interaksi $A B$ (model pembelajaran dan motivasi belajar), nilai statistic uji Fab $=0,136$ dan Ftabel $=3,156$. Fab < Ftabel. Hal ini berarti Fab $\notin$ DK. Dengan demikian $\mathrm{HOAB}$ diterima. Hal ini berarti pada tingkat signifikansi $\alpha=0,05$ tidak terdapat interaksi antara model pembelajaran dengan motivasi belajar matematika siswa.

Pada penelitian ini, terdapat persamaan situasi proses pembelajaran terlihat pada tahap guru mengaitkan materi dengan pengalaman siswa dikehidupan sehari-hari. Berdasarkan hasil uji statistik menggunakan anava dua jalan untuk penerapan model pembelajaran Probing-Prompting (PP) dan Contextual Teaching and Learning (CTL) sebagai variabel bebas dengan hasil belajar sebagai variabel terikat diperoleh hasil yang menyatakan bahwa tidak terdapat perbedaan hasil belajar matematika antara penerapan model pembelajaran PP dan CTL. Hal ini terlihat pada deskripsi data tentang hasil belajar matematika ssiwa kelas X TKR sebagai kelas eksperimen 1 dan $\mathrm{X}$ TKKB sebagai kelas eksperimen 2 .

Perolehan hasil belajar matematika untuk kelas eksperimen satu dengan rata-rata nilai 70,57 dan kelas eksperimen dua dengan rata-rata nilai 73,38 . Terlihat bahwa tidak terdapat perbedaan nilai yang cukup berarti. Hal ini juga sesuai dengan hasil uji statistik menggunakan anava dua jalan $\mathrm{H}_{0}$ diterima. Berdasarkan pembahasan teoritis dan penelitian yang dilakukan dapat disimpulkan bahwa tidak terdapat perbedaan hasil belajar antara penerapan model PP dikelas eksperimen satu dan model CTL dikelas eksperimen dua.

Selama kegiatan belajar mengajar di kelas secara keseluruhan siswa terlihat aktif dan kritis dalam menggali informasi mengenai materi yang disampaikan.Siswa terlihat bersemangat dalam mengikuti pelajaran, siswa cenderung aktif bertanya dan mencari jawaban pada permasalahan 
yang diberikan oleh guru. Namun tidak dapat dikatakan bahwa siswa yang aktif dan kritis memiliki tingkat pemahaman yang tinggi.Seperti yang telah dikemukakan sebelumnya, bahwa motivasi belajar merupakan faktor psikis yang non-intelektual.

Berdasarkan hasil angket motivasi belajar untuk siswa yang memiliki motivasi rendah diperoleh nilai rata-rata sebesar 47,08, siswa yang memiliki motivasi sedang sebesar 71,96, dan siswa yang memiliki motivasi tinggi sebesar 92,83. Sedangkan untuk hasil belajar siswa digolongkan dalam tingkat motivasi, siswa yang memiliki tingkat motivasi rendah memiliki nilai rata-rata sebesar 71,25, siswa yang memiliki tingkat motivasi sedang sebesar 71,89, dan siswa yang memiliki motivasi tinggi sebesar 72,17.

Dilihat dari rata-rata hasil belajar berdasarkan tingkat motivasi, terdapat perbedaan yang tidak terlalu signifikan.Hal ini juga sejalan dengan uji statistik menggunakan anava dua jalan $\mathrm{H}_{0}$ diterima sehingga dapat disimpulkan bahwa tidak terdapat perbedaan hasil belajar antara siswa yang memiliki motivasi rendah, sedang, dan tinggi.

Dari penjelasan diatas dapat dinyatakanbahwa karakteristik perbedaan antara model pembelajaran (PP dan CTL) pada setiap tingkat motivasi belajar adalah sama. Karakteristik tersebut sama dengan karakteristik marginal perbedaan rerata antar model pembelajaran. Berdasarkan hasil uji anava rata-rata marginal antar baris (model pembelajaran) model pembelajaran PP dan CTL tidak terdapat perbedaan hasil belajar. Karena tidak terdapat interaksi, maka hal tersebut juga berlaku pada masing-masing model pembelajaran untuk siswa yang memiliki tingkat motivasi belajar rendah, sedang, dan tinggi, dalam arti bahwa pada siswa yang memiliki tingkat motivasi rendah, sedang, dan tinggi, pada model pembelajaran PP tidak terdapat perbedaan hasil belajar dengan penerapan model pembelajaran CTL.

Berdasarkan hasil uji anava, rerata antar kolom (motivasi belajar), motivasi belajar rendah, sedang, dan tinggi untuk kedua model pembelajaran (PP dan CTL) tidak terdapat perbedaan. Karena tidak terdapat interaksi, maka hal tersebut berlaku untuk tiap tingkat motivasi pada masingmasing model pembelajaran, dalam arti, pada masing-masing model pembelajaran (PPdan CTL) siswa yang memiliki motivasi belajar rendah, sedang, dan tinggi tidak terdapat perbedaan hasil belajar. Jadi, jika tidak terdapat interaksi antara variabel bebas, maka tidak perlu dilakukan uji lanjut pasca anava.

\section{KESIMPULAN}

Berdasarkan hasil penelitian dan pembahasan, disimpulkan bahwa pada siswa kelas X SMK Teladan Kota Batam adalah tidak terdapat perbedaan hasil belajar antara penerapan model pembelajaran Probing-Prompting dan Contextual Teaching and Learning; tidak terdapat perbedaan hasil belajar antara siswa yang memiliki motivasi belajar rendah, sedang, dan tinggi; dan tidak terdapat perbedaan hasil belajar antara siswa yang memiliki motivasi rendah, sedang, dan tinggi pada model pembelajaran Probing-Prompting dan Contextual Teaching and Learning. Penelitian ini diharapkan dapat menjadi sumbangan pengetahuan yang berkaitan dengan subjek maupun objek yang diteliti untuk penelitian selanjutnya. Apabila penelitian ini dilanjutkan diharapkan penelitian dilakukan secara lebih mendalam mengenai pengaruh penerapan berbagai model pembelajaran dan meninjau hasil belajar dari motivasi belajar siswa.

\section{DAFTAR RUJUKAN}

Aris Shoimin. (2016). 68 Model Pembelajaran Inovatif Dalam Kurikulum 2013. Yogyakarta: ArRuzz Media.

Hamzah B. Uno.(2011). Teori Motivasi Dan Pengukurannya. Jakarta: Bumi Aksara.

Huda, M. (2013).Model Pengajaran Dan Pembelajaran. Yogyakarta: Pustaka Pelajar.

Masnur Muslich. (2009). KTSP Pembelajaran Berbasis Kompetensi Dan Kontekstual. Jakarta: Bumi Aksara. 
Pupuh Fathurrohman \& Sobry Sutikno. (2009). Strategi Belajar Mengajar Bandung: PT. Refika Aditama.

Rusman.(2013). Model-Model Pembelajaran. Jakarta: Rajawali Pers.

Sardiman.(2009).Interaksi Dan Motivasi Belajar-Mengajar. Jakarta: Rajawali 